\title{
Vacuolating Megalencephalic Leukoencephalopathy with Subcortical Cysts (Van der Knaap Leukoencephalopathy): A Case Diagnosed in Adulthood
}

\author{
Subkortikal Kistler ile Birlikte Vakuolize Megalensefalik Lökoensefalopati (Van der \\ Knaap Lökoensefalopatisi): Erişkin Yaşta Tanı Alan Bir Olgu
}

\author{
1Bakırköy Prof. Dr. Mazhar Osman Research and Training Hospital for Neuropsychiatry, Clinic of $3^{\text {rd }}$ Neurology, İstanbul, Turkey \\ 2Erenköy Research and Training Hospital for Neuropsychiatry, Clinic of Neurology, İstanbul, Turkey \\ 3istanbul University Cerrahpaşa Faculty of Medicine, Department of Forensic Medicine, İstanbul, Turkey
}

\section{Summary}

Van der Knaap leukoencephalopathy is a rare vacuolating megalencephalic leukoencephalopathy with subcortical cysts. It is inherited autosomal recessively with MLC1 and GlialCAM mutations. The disease is usually diagnosed in the patient's first years of childhood and symptoms are severe in adulthood. In this case, a male patient aged 35 years presented with pathologic cerebellar and pyramidal findings. Magnetic resonance imaging revealed bilateral cystic degeneration in the anterior temporal lobes, swelling in the supratentorial white matter, and abnormal signal. There were no pathologic findings in the differential diagnosis tests. The patient was diagnosed as having Van der Knaap leukoencephalopathy according to the clinical and radiologic findings.

Keywords: Van der Knaap leukoencephalopathy, vacuolating megalencephalic leukoencephalopathy, macrocephaly

$\ddot{\mathbf{O z}}$

Van der Knaap lökoensefalopatisi, subkortikal kistler ile birlikte görülen vakuolize megalensefalik bir lökoensefalopatidir ve nadir görülmektedir. MLC1 ve GlialCAM mutasyonu ile otozomal resesif olarak kalıtılmaktadır. Hastalar çoğunlukla hayatın ilk yıllarında tanı alır ve erişkin yaşlarda ağır klinik Tablelar ile prezente olurlar. Bu olguda, patolojik piramidal ve serebellar muayene bulguları olan 35 yaşında erkek hasta sunulmaktadır. Hastada manyetik rezonans görüntüleme ile bilateral anterior temporal loblarda kistik dejenerasyon, supratentoryal beyaz maddede hacim artışı ve anormal sinyal varlı̆̆ı saptanmıştır. Ayırıcı tanı için yapılan diğer tetkiklerde özellik saptanmamıştır. Klinik ve radyolojik bulgular doğrultusunda Van der Knaap lökoensefalopatisi tanısı konulmuştur.

Anahtar Kelimeler: Van der Knaap lökoensefalopatisi, vakuolize megalensefalik lökoensefalopati, makrosefali

\section{Introduction}

Vacuolating megaloencephalia with subcortical cysts (MLC) was first defined by Van der Knaap in 1995 (1). Clinical features can be listed as macrocephaly in the first year, growth retardation of varying degrees, slow onset cerebellar and pyramidal disorders, spasticity, ataxia, preserved mental capacity in the beginning, and seizures $(2,3)$.

Magnetic resonance imaging (MRI) shows bilateral cystic degeneration of the anterior temporal and frontoparietal lobes, volume expansion, and diffuse abnormal hyperintense signal in the supratentorial white matter in T2 and fluid-attenuated inversion recovery-weighted images (4).

This disease is an autosomal recessive disorder and the related gene (MLC1) is located in chromosome 22q $(2,5)$. Seventy-five percent of Van der Knaap patients have this mutation (6). The latest studies show that the remaining $25 \%$ of patients have Glial CAM (HEPACAM) - an adhesion molecule-mutation $(6,7,8)$. There are few reported adult patients because most patient's disease is diagnosed in early childhood (9).

Address for Correspondence/Yazışma Adresi: Fulya Eren MD, Bakırköy Prof. Dr. Mazhar Osman Research and Training Hospital for Neuropsychiatry, Clinic of $3^{\text {rd }}$ Neurology, İstanbul, Turkey

Phone: +90 2125436565 E-mail: fulyasengul@yahoo.com

Received/Geliş Tarihi: 11.11.2014 Accepted/Kabul Tarihi: 11.01.2015 
This case report discusses a patient whose disease was diagnosed at adult age with clinical and radiologic features, and the related literature.

\section{Case Report}

A male patient aged 35 year presented to our clinic with an increase in his existing walking trouble and loss of sensation, pain, and weakness in both arms. The patient's walking difficulties began when he was aged 6 years and progressed slowly until presentation. Loss of sensation, pain, and weakness in his upper extremities started one month ago. His birth and early childhood history was normal. His motor and mental development was normal. The patient's highest reported level of education was elementary grade. His right eye was totally blind and opthalmoparetic due to a previous injury at work. His parents were second degree relatives. He reported no use of alcohol or cigarettes. The patient was no using any prescription medicine.

The findings of the patient's neurologic examination showed external deviation and adduction palsy of the left eye, $-5 / 5$
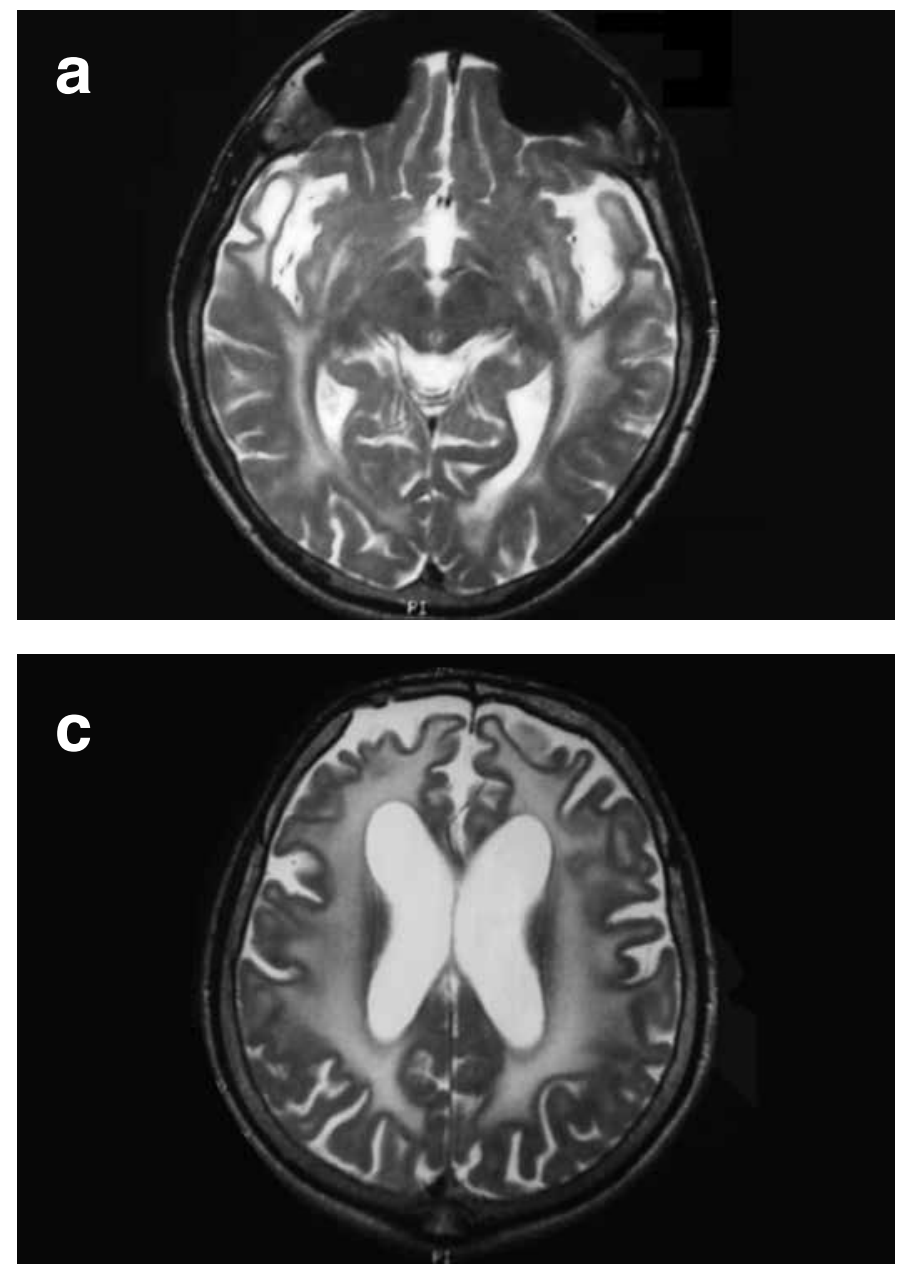

paralysis of the left leg, increased reflexes in all four extremities, equivocal plantar reflexes in both toes, impaired cerebellar tests in all four extremities, and spastic gait. His head circumference was measured as $64 \mathrm{~cm}$. Other components of the neurologic examination were normal. Wechsler adult intelligence scale (WAIS) showed limited mental capacity.

Cranial MRI showed diffuse bilateral cerebral subcortical and deep white matter hyperintensity in T2 weighted images (Figure $1 \mathrm{a}, 1 \mathrm{~b}, 1 \mathrm{c})$. The abnormal signal was present in the subcortical frontal and parietal $U$ fibers (Figure 1a, 1c). Subcortical $U$ fibers were partially spared in the posterior temporal and occipital lobes (Figure 1c). The anterior temporal lobes were also affected all the way up to the cortex. There were wide cysts that were isointense with cerebrospinal fluid in anterior temporal lobe (Figure 1d). The cortical sulci and lateral ventricles were enlarged due to moderate cerebral cortical atrophy. The patient was referred to neuroradiology and was subsequently diagnosed as having Van der Knaap leukoencephalopathy with these findings.

Other diseases that result in leukodystrophy were excluded with a detailed biochemical analysis including serum hexosaminidase $\mathrm{A}$ and
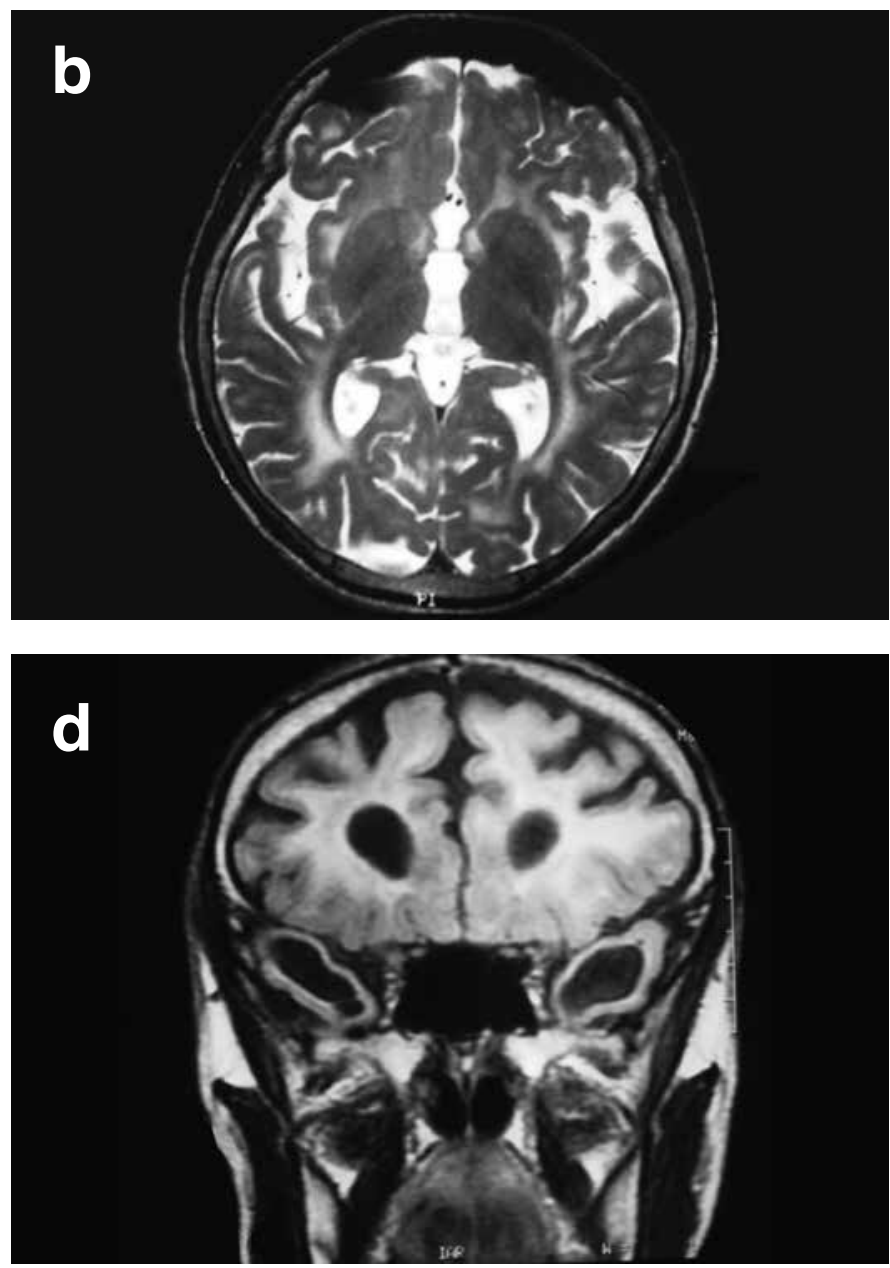

Figure 1. a) The subcortical U fibers are partially spared in the posterior temporal and occipital lobes, b) the T2 weighted image cutting through corona radiata shows the affected subcortical U fibers in both cerebral hemispheres. Basal ganglia were spared. c) T2 weighted image cutting through the centrum semiovale shows the abnormal hyperintensity of white matter in both cerebral hemispheres. The abnormal signal continues to the cortex including the subcortical U fibers. d) Coronal T1 weighted image shows bilateral anterior temporal cysts 
arylsulphatase A levels. Hepatomegaly was found in an abdominal ultrasound. Liver function tests and viral hepatitis markers were found to be negative including serum CMV IgM and IgG. Blood count, serum $\mathrm{Fe}$ and $\mathrm{Cu}$, lipid profile and liver-specific tumor markers were also normal. Electromyography showed mild carpal tunnel syndrome.

\section{Discussion}

There are various theories in the pathophysiology of Van der Knaap leukoencephalopathy, such as vacuole formation between myelin lamellas, demyelination or dysmyelination and increase in the extracellular space (1). The distinctive feature is the slow progressive functional loss, despite massive white matter involvement. There may be a blood relationship in the parents and there can be multiple patients in the same family because of the autosomal recessive inheritance (4).

One of the most common clinical features of Van der Knaap leukoencephalopathy is macrocephaly. It is usually found at birth or develops in the first year of life. Macrocephaly may be as much as 4 to 6 standard deviations above the average $(54-62 \mathrm{~cm})(10)$. Our patient was macrocephalic with a head circumference of $64 \mathrm{~cm}$. Early development is usually normal despite the white matter lesions and macrocephalia. Motor function deteriorates over time because of the progressive ataxia and spasticity $(4,10)$. Mental impairment does not develop in tandem with the motor deficits (11). Pyramidal and extrapyramidal symptoms (e.g. chorea, athetosis) may develop in later stages. The previous reported cases were often diagnosed in early childhood or infanthood and clinical features were more severe when they reached adulthood (12). In our patient the pyramidal symptoms started at the age of 6 and his disease was diagnosed at 35 years. WAIS showed limited mental capacity. It is remarkable that there are few reported cases diagnosed in adulthood with such mild symptoms (13).

Most patients have seizures and respond well to anti-epileptic treatment $(9,11)$. Our patient had no history of seizures.

Hepatomegaly was present in our patient. Tests to determine the cause of hepatomegaly were non-significant. To our knowledge, there are no reported cases of Van der Knaap leukoencephalopathy with concomitant hepatomegaly.

Other diseases that cause infantile megalencephalic leukoencephalopathy are Canavan disease, Alexander disease, glutaric aciduria type 1, GM1 gangliocidosis, L2 hydroxyglutaric aciduria. These diseases differ from Van der Knaap leukoencephalopathy clinically, radiologically and biochemically $(5,14)$. There is a lack of myelination with widespread spongy degeneration in Canavan disease (15). Periventricular rim, basal ganglia, thalamic and brain stem abnormalities are present in Alexander's disease (16). Our patient showed none of the characteristic radiologic findings of the mentioned diseases. Diffuse white matter abnormalities and swelling with cyst-like spaces are specific findings of Van der Knaap megalencephalic leukoencephalopathy (1).

No metabolic defect for Van der Knaap leukoencephalopathy has been shown to date. The diagnosis depends on the characteristic clinical features and neuroradiologic findings. For cases with atypical presentation, genetic analysis should provide an accurate diagnosis. We did not perform a genetic analysis in our patient. There's no defined curative approach for this disease and the current treatment is symptomatic with supportive psychotherapy.

\section{Authorship Contributions}

Informed Consent: A consent form was completed by the patient. Concept: Günay Gül, Fulya Eren, Gönül Özay, Dursun Kirbaş, Design: Günay Gül, Fulya Eren, Data Collection or Processing: Günay Gül, Fulya Eren, Analysis or Interpretation: Fulya Eren, Gönül Özay, Literature Search: Günay Gül, Fulya Eren, Gönül Özay, Writing: Günay Gül, Fulya Eren, Gönül Özay, Peer-review: Externally peerreviewed. Conflict of Interest: No conflict of interest was declared by the authors. Financial Disclosure: The authors declared that this study has received no financial support.

\section{References}

1. Arnedo T, López-Hernández T, Jeworutzki E, Capdevila-Nortes X, Sirisi S, Pusch M, Estévez R. Functional analyses of mutations in HEPACAM causing megalencephalic leukoencephalopathy. Hum Mutat 2014;35:1175-1178.

2. Bajaj SK, Misra R, Gupta R, Chandra R, Malik A. Megalencephalic leukoencephalopathy with sub cortical cysts: An inherited dysmyelinating disorder. J Pediatr Neurosci 2013;8:77-80.

3. Chen CY, Zimmerman RA, Lee CC, Chen FH, Yuh YS, Hsiao HS Neuroimaging findings in late infantile GM1 gangliosidosis. AJNR Am J Neuroradiol 1998;19:1628-1630.

4. Harbord MG, Harden A, Harding B, Brett EM, Baraitser M. Megalencephaly with dysmyelination, spasticity, ataxia, seizures and distinctive neurophysiological findings in two siblings. Neuropediatrics 1990;21:164-168.

5. Hari Krishnan K, Leema Pauline C, Kumaresan G, Vasantha Mallika TK. Megalencephalic leukoencephalopathy with subcortical cysts. Indian Pediatr 2005;42:60-63.

6. Jeworutzki E, Lagostena L, Elorza-Vidal X, López-Hernández T, Estévez R, Pusch M. GlialCAM, a CLC-2 Cl(-) channel subunit, activates the slow gate of CLC chloride channels. Biophys J 2014;107:1105-1116.

7. Kocaman G, Eryigit G, Abbink TE, Kilıcarslan R, Asil T, Alkan A, Van der Knaap MS, Kocer A. An unusually mild presentation of megalencephalic leukoencephalopathy with subcortical cysts. Clin Neurol Neurosurg 2013;115:1564-1566.

8. Koul R, Al-Thihli K, Al-Azri F, Al-Futaisi A. Megalencephalic leukoencephalopathy with subcortical cysts. Sultan Qaboos Univ Med J 2013;13:585-586.

9. Matalon R, Rady PL, Platt KA, Skinner HB, Quast MJ, Campbell GA, Matalon K, Ceci JD, Tyring SK,Nehls M, Surendran S, Wei J, Ezell EL, Szucs S. Knockout mouse for Canavan disease: a model for gene transfer to the central nervous system. J Gene Med 2000;2:165-175.

10. Patrono C, Di Giacinto G, Eymard-Pierre E, Santorelli FM, Rodriguez D, De Stefano N, Federico A, Gatti R, Benigno V, Megarbané A, Tabarki B, Boespflug-Tanguy O, Bertini E. Genetic heterogeneity of megalencephalic leukoencephalopathy and subcortical cysts. Neurology 2003;61:534-537.

11. Singhal BS, Gorospe JR, Naidu S. Megalencephalic leukoencephalopathy with subcortical cysts. J Child Neurol 2003;18:646-652.

12. Topçu M, Gartioux C, Ribierre F, Yalçinkaya C, Tokus E, Oztekin N, Beckmann JS, Ozguc M, Seboun E. Vacuoliting megalencephalic leukoencephalopathy with subcortical cysts, mapped to chromosome 22qPhone Am J Hum Genet 2000;66:733-739.

13. van der Knaap MS, Barth PG, Stroink H, van Nieuwenhuizen O,Arts WF Hoogenraad F,Valk J. Leukoencephalopathy with swelling and a discrepantly mild clinical course in eight children. Ann Neurol 1995;37:324-334.

14. van der Knaap MS, Naidu S, Breiter SN, Blaser S, Stroink H, Springer S, Begeer JC, van Coster R, Barth PG, Thomas NH, Valk J, Powers JM. Alexander disease: diagnosis with MR imaging. AJNR Am J Neuroradiol 2001;22:541-552.

15. Yalcinkaya C, Benbir G, Salomons GS, Karaarslan E, Rolland MO, Jakobs C, van der Knaap MS. Atypical MRI findings in Canavan disease: a patient with a mild course. Neuropediatrics 2005;36:336-339.

16. Yalçinkaya C, Yüksel A, Comu S, Kiliç G, Cokar O, Dervent A. Epilepsy in vacuolating megalencephalic leukoencephalopathy with subcortical cysts. Seizure 2003;12:388-396. 